\title{
Role of nitric oxide in optic nerve head blood flow regulation while experimental increase of ocular perfusion pressure
}

\author{
Reinhard Told ${ }^{1}$, Doreen Schmidl ${ }^{1,2}$, Michael Lasta ${ }^{1}$, Agnes Boltz ${ }^{3}$, Berthold Pemp ${ }^{2}$, Semira Kaya ${ }^{1}$, Gerhard Garhöfer ${ }^{1}$, \\ Gabriele Fuchsjäger-Mayrl' ${ }^{2}$ Leopold Schmetterer ${ }^{1,3^{*}}$
}

From 17th Scientific Symposium of the Austrian Pharmacological Society (APHAR). Joint meeting with the Hungarian Society of Experimental and Clinical Pharmacology (MFT)

Innsbruck, Austria. 29-30 September 2011

\section{Background}

The involvement of nitric oxide (NO) in choroidal blood flow regulation during experimental increase of ocular perfusion pressure (OPP) has been shown in previous studies. It is also known that during isometric exercise, the inhibition of NO synthase (NOS) leads to a rightward shift of pressure-flow curves. In this study the influence of inhibited NOS on optic nerve head (ONH) blood flow during isometric exercise was investigated.

\section{Methods}

A randomized, double-blinded, placebo-controlled, threeway crossover design was chosen for the present study. In order to increase systemic perfusion pressure during application of either a NOS inhibitor (L-NMMA), an $\alpha$ receptor agonist (phenylephrine) or placebo, 18 healthy subjects were asked to squat for 6 minutes. Laser Doppler flowmetry (LDF) was used for continuous assessment of ONH blood flow and OPP was calculated as $2 / 3$ mean arterial pressure minus intraocular pressure (IOP).

\section{Results}

L-NMMA and phenylephrine both significantly increased OPP at rest ( $\mathrm{p}<0.001$ vs. baseline). However, only L-NMMA significantly decreased ONH blood flow at rest compared to baseline $(\mathrm{p}=0.02)$. While isometric exercise was performed and using all three drugs administered, no difference in ONH blood flow and OPP response was recorded $(\mathrm{p}=0.43$ and $\mathrm{p}=0.69$, respectively).

\footnotetext{
* Correspondence: leopold.schmetterer@meduniwien.ac.at

'Department of Clinical Pharmacology, Medical University of Vienna, 1090 Vienna, Austria

Full list of author information is available at the end of the article
}

\section{Conclusions}

The findings of this study indicate that NO seems to be involved in basal regulation of ONH blood flow. However, this was not the case during isometric exercise. Whether different regulatory systems gain importance after increase of OPP and blood flow has to be the focus of further studies.

\section{Author details}

'Department of Clinical Pharmacology, Medical University of Vienna, 1090 Vienna, Austria. ${ }^{2}$ Department of Ophthalmology and Optometry, Medical University of Vienna, 1090 Vienna, Austria. ${ }^{3}$ Center for Medical Physics and Biomedical Engineering, Medical University of Vienna, 1090 Vienna, Austria.

Published: 5 September 2011

doi:10.1186/1471-2210-11-S2-A47

Cite this article as: Told et al:: Role of nitric oxide in optic nerve head blood flow regulation while experimental increase of ocular perfusion pressure. BMC Pharmacology 2011 11(Suppl 2):A47.

Submit your next manuscript to BioMed Central and take full advantage of:

- Convenient online submission

- Thorough peer review

- No space constraints or color figure charges

- Immediate publication on acceptance

- Inclusion in PubMed, CAS, Scopus and Google Scholar

- Research which is freely available for redistribution

Submit your manuscript at www.biomedcentral.com/submit

\section{Biomed Central}

(c) 2011 Told et al; licensee BioMed Central Ltd. This is an open access article distributed under the terms of the Creative Commons Attribution License (http://creativecommons.org/licenses/by/2.0), which permits unrestricted use, distribution, and reproduction in any medium, provided the original work is properly cited. 